\title{
The role of historical and ecological factors on initial survival of Copaifera langsdorffii Desf. (Fabaceae)
}

\author{
Marcílio Fagundes ${ }^{1,4}$, Fernanda Vieira da $\operatorname{Costa}^{1,2}$, Suélen Ferreira Antunes ${ }^{1}$, Maria Luiza Bicalho Maia ${ }^{1}$, \\ Antônio César Medeiros de Queiroz ${ }^{1}$, Leonardo Queiroz Oliveira ${ }^{1}$ and Maurício Lopes de Faria ${ }^{3}$
}

Received: 5 September, 2012. Accepted: 4 July, 2013

\begin{abstract}
The plant population dynamic is affected by ecological and evolutionary processes that operate at all stages of the plant life cycle. The aim of this study was to characterize the seed and seedling performance of Copaifera langsdorffii by testing four hypotheses: the resource concentration hypothesis; the relationship between seed size and germinability hypothesis; the relationship between seed size and seedling vigor hypothesis; and the intraspecific seedling competition hypothesis. All seeds used in the experiments were collected from 35 C. langsdorffii plants located in a fragment of the Brazilian cerrado (savanna). The number of fruits per plant negatively affected Rhinochenus brevicollis attacks on C. langsdorffii seeds. Therefore, this result does not support the resource concentration hypothesis, and predator satiation was used in order to explain the observed result. In general, seed germinability (percentage and time to emergence) was not influenced by seed size. The homogeneity of the experimental design, together with an abundant water supply, may have masked the effects of seed size on germinability. Seed size positively affected seedling development, corroborating the expected relationship between seed size and seedling vigor. The number of seedling per plastic bags negatively affected the growth of C. langsdorffii. The nutrient-limited soil probably promoted the below-ground competition for nutrients among seedlings. Finally, the role of evolutionary and ecological factors on C. langsdorffii population dynamics is discussed.
\end{abstract}

Key words: plant competition, predation, Rhinochenus brevicollis, seed size, seedling development

\section{Introduction}

The reproductive success of plants is affected by historical factors (e.g., seed size, seed number and plant phenology) and ecological factors (e.g., competition, herbivory, pollination, seed dispersion and predation) operating at all stages of the plant life cycle (Marques \& Oliveira 2005; Czarnecka \& Władyka 2007; Bu et al. 2009). Characterizing the role of historical and ecological factors on adult plants (fruit and seed sets) and young plants (seed germination rates and seedling performance) is central to understanding the mechanisms that regulate the plant population dynamics and community organization (Alcántara et al. 2004; Moles \& Westoby 2006). The effects of these historical and ecological factors on plant performance may be estimated by quantifying the number/viability of the seeds produced by individual plants; by estimating the relationship between seed biomass, seed germinability and seedling performance; and by accessing the effects of competition on seedling development (Suscko \& Lovett-Doust 1999; Czarnecka \& Władyka 2007).

Seed predation is one of the major ecological and evolutionary factors affecting plant population dynamics (Hulme \& Benkman 2002; Lewis \& Gripenberg 2008), and chewing insects, such as those of the families Bruchidae and Curculionidae, are important seed predators in several systems (Jazen 1971; Janzen 1975; Loulda et al. 1990). While most research on insect seed predation has focused on forest systems (Ramírez \& Traveset 2010), very few studies are available about seed predation in the cerrado (savanna) of Brazil (Francisco et al. 2008). In addition, the percentage seed predation during pre-dispersal phase may vary widely between species and habitats (Turner et al. 1996; Lewis \& Gripenberg 2008), and the mechanisms that determine these variations deserve more attention. Many hypotheses have been advanced to explain the patterns of herbivorous insect attacks on plant hosts. For example, the Resource Concentration Hypothesis (Root 1973) predicts higher numbers of

\footnotetext{
${ }^{1}$ Universidade Estadual de Montes Claros, Centro de Ciências Biológicas e da Saúde, Departamento de Biologia Geral, Laboratório de Biologia da Conservação, Montes Claros, MG, Brazil

${ }^{2}$ Instituto Nacional de Pesquisa na Amazônia, Coordenação de Pesquisas em Ecologia, Manaus, AM, Brazil

${ }^{3}$ Universidade Estadual de Montes Claros, Centro de Ciências Biológicas e da Saúde, Departamento de Biologia Geral, Laboratório de Controle Biológico, Montes Claros, Minas Gerais, Brazil

${ }^{4}$ Author for correspondence: marcilio.fagundes@gmail.com
} 
herbivore attacks on more dense resource matches. In this context, it is likely that plants producing greater numbers of fruits will be attacked by seed predator insects more often.

Seed size is another plant attribute that greatly affects the reproductive success of plants (Cordazzo 2002; Baraloto \& Forget 2007). It has been theoretically argued that germinability is associated with life history attributes such as seed size, seed dispersal syndrome and life form ( $\mathrm{Bu}$ et al. 2009). Generally, it is assumed that smaller seeds germinate faster and present a competitive advantage in unpredictable habitats (e.g., early successional stages). Conversely, larger seeds germinate more slowly but present a higher percentage germination. Therefore, larger seeds are favored in more predictable habitats (e.g., late successional stages) especially because they have more nutrient reserves (Harper 1977; Geritz 1995; Ferreira \& Borghetti 2004; Baraloto \& Forget 2007). However, some studies also suggest the absence of a relationship between seed size and seed germinability (Kaydan \& Yagmur 2008).

Seed size can also affect seedling performance in an ecological and historical context. In fact, larger seeds commonly produce more vigorous and resistant seedlings (Kidson \& Westoby 2000; Green \& Juniper 2004). However, the outcome of the interaction between seed size and seedling performance can be affected by microhabitat characteristics (Rey et al. 2004; Baraloto \& Forget 2007; Fagundes et al. 2011). Therefore, seed size may be part of synchronized sets of plant life history traits, which govern the distribution of new seedlings in space and time (Moles et al. 2005).

After seed germination, intraspecific and interspecific ecological interactions can also negatively affect plant establishment (Dickie et al. 2005; Casper \& Jackson 1997). The competition among seedlings can occur below ground (Plat et al. 2004) and above ground (Kull et al. 2011). Above-ground competition is basically associated with light interception and, generally, plants that present faster development have higher competitive ability (Lemaire 2001). Below ground, plants can also compete for water, essential minerals, and space for root growth. Moreover, the results of competition among plants can be affected by interactions occurring above and below ground. For example, seedling with high ability to absorb nutrients can be negatively affected by shade, even in nutrient-rich soils (Lentz 1999, Platt et al. 2004). Therefore, a range of factors (e.g., seed predation, seed size, seed-habitat interaction and seedling competition) can interact and determine the success of plant establishment.

Copaifera langsdorffii Desf. (Fabaceae) is an important tree species of the Brazilian cerrado, and can reach up to $10 \mathrm{~m}$ in height (Ribeiro et al. 2001). The plants drop their leaves during the dry season (July to September) and the emission of new leaves begin immediately after the fall of leaves produced in the previous growing season (Pedroni et al. 2002). Fructification is supra-annual, i.e., alternating, yearby-year, between intense fruit production and little or no fruit production (Pedroni et al. 2002). The C. langsdorffii seeds present orthodox behavior and germinates slowly, taking up to 70 days (Bezerra 2002). Seed predation by Rhinochenus brevicollis Chevrolat (Curculionidae: Cryptorhynchinae) occurs in the pre-dispersal phase. The beetle represents an important mortality factor of $C$. langsdorffii seeds, although others animals also attack these seeds in the pre-dispersal stage (Freitas \& Oliveira 2002; Fagundes et al. 2013).

The objective of this study was to characterize seed and seedling performance of Copaifera langsdorffii by testing four hypotheses: the resource concentration hypothesis, which predicts higher rates of herbivore attacks on more dense resource patches; the relationship between seed size and germinability hypothesis, which suggests that large seeds germinate more slowly but present higher germinability; the relationship between seed size and seedling vigor hypothesis, which predicts that larger seeds produce more vigorous seedlings; and the intraspecific competition hypothesis, which suggests diminishing growth rates when a limiting resource is partitioned among individuals.

\section{Material and methods}

\section{Seed predation of Copaifera langsdorffii}

The fruit predation experiment was conducted in an area of cerrado (16 $40^{\prime} 26^{\prime \prime}$; $\left.43^{\circ} 48^{\prime} 44^{\prime \prime} \mathrm{W}\right)$ near the city of Montes Claros, in the state of Minas Gerais, Brazil. The region is considered a phytophysiognomic transition between the morphoclimatic domains of caatinga (shrublands) and cerrado (Rizzini 1997). The climate of the region is semiarid, with well-defined dry and rainy seasons. The average annual temperature is $23^{\circ} \mathrm{C}$, and the average precipitation is $1100 \mathrm{~mm} /$ year, the rainy season being from November to January. Specifically, the study area is cerrado with dystrophic soil, presenting tortuous trees, 3-10 m height, with thick barks and sclerophyllous leaves (Costa et al. 2011; Fagundes et al. 2011).

A total of 35 Copaifera langsdorffii reproductive trees, 4.5-6.5 $\mathrm{m}$ in height, were marked in the study area during May 2008 (period of fruit development) and ten terminal branches were collected from each selected plant. The branches were collected at different points of the tree crown to minimize possible microclimatic effects on plant growth or herbivory. Those branches were approximately $30 \mathrm{~cm}$ long, corresponding to the last season of plant growth, with completely expanded leaves. All branches were individually bagged and taken to the Laboratory of Conservation Biology of the State University of Montes Claros, where the fruits were counted and average fruits per branch was determined for each tree. This sampling technique showed high efficiency in evaluating herbivore attacks on C. langsdorffii (see Costa et al. 2010). The number of fruits per plant was determined by multiplying plant height by the mean number of fruits per branch. Finally, in July 2008 
(at fruit maturation, before seed dispersal), one hundred fruits were collected from each marked plant to estimate seed predation by Rhinochenus brevicollis. The effect of the number of fruits per plant on $R$. brevicollis attack (number of seeds attacked) was tested using a general linear model with Poisson error distribution.

\section{Seed morphometry and seedling emergence}

One hundred fruits were collected from each of the 35 marked plants in study area. All collected fruits were opened, and all ill-formed (possibly aborted) seeds or those with signs of damage or predation were discarded. A remaining set of 1575 seeds (approximately 45 seed per plant) was used to characterize seed morphometry and germinability. The morphometric characteristics of each seed (length, width and thickness) were measured with a digital caliper.

After morphometric characterization of the seeds, we filled 525 black plastic bags $(35 \mathrm{~cm}$ in height and $15 \mathrm{~cm}$ in diameter) with soil collected from the same area of cerrado in which the plants were marked $(\mathrm{pH}=6.1$; Mehlich $\mathrm{P}=6$ $\mathrm{mg} . \mathrm{dm}^{-3} ;$ potassium $=0.6 \mathrm{mg} \cdot \mathrm{dm}^{-3} ;$ aluminum $=0.4 \mathrm{~mol}$. $\mathrm{dm}^{-3}$; sum of bases $=0.1 \mathrm{~mol} . \mathrm{dm}^{-3}$; organic matter $=19.9$ g.kg ${ }^{-1}$; sand $=442.2 \mathrm{~g} . \mathrm{kg}^{-1}$; clay $=39.0 \mathrm{~g} \cdot \mathrm{kg}^{-1}$ ), to be used as the substrate for seedling emergence. The 1575 seeds were divided equally among the 525 bags (three seeds per bag) and were sown $2 \mathrm{~cm}$ deep, equidistant from each other (10 $\mathrm{cm})$. Each seed was identified with a numbered tag for daily monitoring from sowing to seedling emergence. This experiment was conducted in a greenhouse, where each plastic bag received approximately $0.5 \mathrm{~L}$ of water per day but temperature was not controlled. Seedling emergence was evaluated daily for a period of 70 days after sowing. Seedling emergence was defined as the emergence of the cotyledon from the substrate.

The effects of seed morphometrics (length, width and thickness) on time to seeding emergence were tested by regression analysis. Those parameters (seed length, width and thickness) were used as independent variables, whereas time to emergence was the dependent variable. The chisquare test was applied in order to evaluate the effect of seed morphometrics (length, width and thickness) on seedling emergence. In this case, all morphometric variables were categorized by seed size class, and the observed and expected percentage emergence was determined for each class. The overall percentage seedling emergence was used in order to determine the expected percentage seedling emergence within each seed size class. Differences between the expected and observed percentage emergence were also tested using the chi-square test.

\section{Seed morphometry and seedling vigor}

A total of 200 seeds were sown in plastic bags and cultivated for 120 days in a greenhouse, as described in the previous section, in order to evaluate the effects of seed morphometrics (length, width and thickness) on seedling development. All seedlings surviving to day 120 after sowing $(\mathrm{n}=172)$ were carefully removed and root and shoot length $(\mathrm{mm})$, and root and shoot dry mass $\left(\mathrm{mg}^{\text {p.plant }}{ }^{-1}\right)$ were measured. The dry masses of seedling parts were measured after drying samples at $70^{\circ} \mathrm{C}$ in a drying oven to a constant weight. The effects of seed morphometrics (length, width and thickness) on seedling development (length and dry mass of roots and shoots) were tested using linear regression. Seed morphometrics were used as independent variables, whereas seedling measurements (length and dry mass of roots and shoots) were the dependent variables.

\section{Intraspecific competition and seedling development}

A set of 1200 seeds were sown and cultivated, as described above, for 120 days in order to evaluate the effects of intraspecific competition among Copaifera langsdorffii seedlings. Seeds were grouped in three treatments: $t_{1}=$ one seed per plastic bag $(n=200), t_{2}=$ two seeds per plastic bag $(n=400)$ and $t_{3}=$ three seeds per plastic bag $(n=600)$. At 120 days after sowing, all seedlings in plastic bags that preserved the initial experimental design (number of seedlings per plastic bag) were removed from their plastic bags $\left(\mathrm{t}_{1}: \mathrm{n}=172 ; \mathrm{t}_{2}: \mathrm{n}=300 ; \mathrm{t}_{3}: \mathrm{n}=312\right)$ in order to determine the dry masses and lengths of the roots and shoots. The dry masses of seedling parts were measured after drying samples to a constant weight in an oven at $70^{\circ} \mathrm{C}$. Differences in root and shoot length and root and shoot dry mass among treatments were tested using ANOVA followed by contrast tests.

\section{Results}

\section{Seed predation}

The mean proportion of Copaifera langsdorffii seeds attacked by Rhinochenus brevicollis was $9.31 \pm 6.41 \%$ (range $1-30 \%)$. The number of fruits per plant was negatively associated with insect predator attacks on seeds $\left(\chi^{2}=6.685\right.$; $\mathrm{p}=0.009$; Fig. 1$)$, indicating that seed predation was greater on plants that produced lower number of fruits.

\section{Seed morphometry and germinability}

The Copaifera langsdorffii seedlings began to emerge at 14 days after sowing and continued to emerge until day 60 after sowing, although most seeds emerged between days post-sowing days 17 and 36 (Fig. 2). As can be seen in Fig. 3, neither seed length nor seed width was associated with time to emergence ( $\mathrm{p}=0.198 ; \mathrm{F}=1.654$ and $\mathrm{p}=0.08 ; \mathrm{F}=2.88$, respectively). However, seed thickness showed positive associations with time to emergence $(\mathrm{F}=91.54 ; \mathrm{p}=0.0001$; $\left.r^{2}=0.067 ; y=9.827+0.26 x\right)$. In addition, the chi-square tests indicated that the percentage emergence of $C$. langsdorffii seeds did not vary among seed size classes (length: $\chi^{2}=2.76$, 


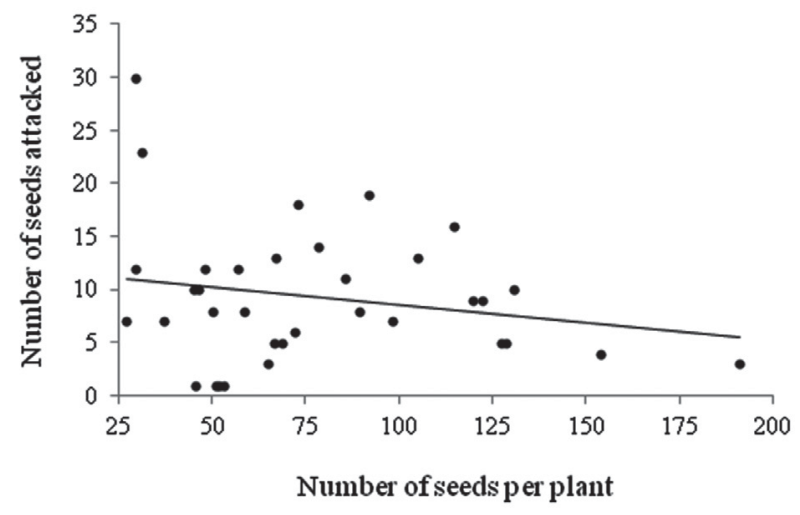

Figure 1. Relationship between mean number of fruits/seeds per plant and Copaifera langsdorffii seed predation by Rhinochenus brevicollis.

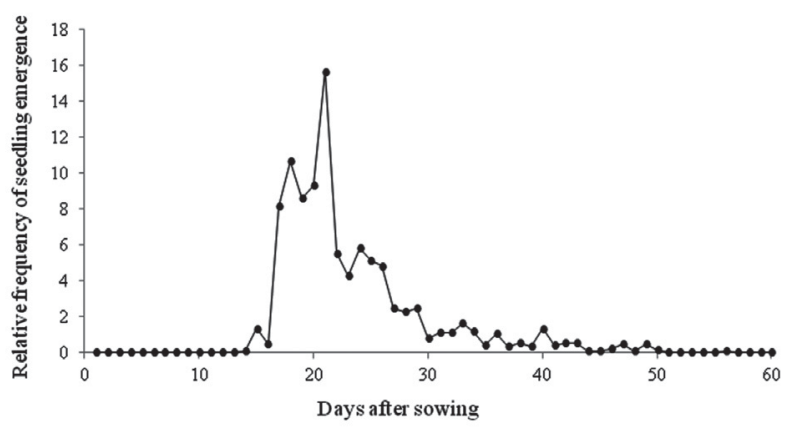

Figure 2. Relative frequency of Copaifera langsdorffii seedling emergence over the first 60 days after sowing in greenhouse conditions. $\mathrm{p}=0.948$, d.f. $=8$; width: $\chi^{2}=2.328, \mathrm{p}=0887$, d.f. $=6$; thickness: $\chi^{2}=0.845, p=0.996$, d.f. $=7$ ).

Fig. 4 shows that seed length was positively associated with seedling shoot length $\left(\mathrm{F}=4.604 ; \mathrm{p}=0.03 ; \mathrm{r}^{2}=0.026\right.$; $\mathrm{y}=10.029+0.162 \mathrm{x})$, as was seed thickness $(\mathrm{F}=5.676$; $\left.\mathrm{p}=0.018 ; \mathrm{r}^{2}=0.032 ; \mathrm{y}=9.893+0.18 \mathrm{x}\right)$, although seed width was not $(\mathrm{p}=0.197 ; \mathrm{F}=1.673)$. In addition, seed length was positively associated with shoot dry mass $(\mathrm{F}=4.258 ; \mathrm{p}=0.04$; $\left.\mathrm{r}^{2}=0.024 ; \mathrm{y}=0.956+0.156 \mathrm{x}\right)$, as was seed width $(\mathrm{F}=6.97$; $\left.\mathrm{p}=0.009 ; \mathrm{r}^{2}=0,042 ; \mathrm{y}=0.429+0.198 \mathrm{x}\right)$. However, seed thickness did not show any association with shoot dry mass $(\mathrm{p}=0.42 ; \mathrm{F}=0.626)$.

As shown in Fig. 5, seed morphometrics were not associated with seedling root length (seed length: $\mathrm{p}=0.68, \mathrm{~F}=0.167$; seed width: $\mathrm{p}=0.21, \mathrm{~F}=1.56$; seed thickness: $\mathrm{p}=0.43, \mathrm{~F}=0.60$ ). However, seed morphometrics were positively associated with seedling dry mass (seed length: $\mathrm{F}=5.29, \mathrm{p}=0.023$, $\mathrm{r}^{2}=0.021, \mathrm{y}=0.572+0.173 \mathrm{x}$; seed width: $\mathrm{F}=17.47, \mathrm{p}=0.0001$, $\mathrm{r}^{2}=0.09, \mathrm{y}=-0.52+0.305 \mathrm{x}$; seed thickness: $\mathrm{F}=6.54, \mathrm{p}=0.01$, $\left.r^{2}=0.03, y=0.587+0.186 x\right)$.

\section{Intraspecific competition}

We observed differences among the three treatments in terms of Copaifera langsdorffii seedling shoot length $(\mathrm{F}=26.14 ; \mathrm{p}<0.01)$, shoot dry mass $(\mathrm{F}=60.57 ; \mathrm{p}<0.01)$ and root dry weight $(\mathrm{F}=30.82 ; \mathrm{p}<0.001)$, as shown in Fig. 6 . However, there were no differences among the treatments in terms of the seedling root length $(\mathrm{p}=0.258 ; \mathrm{F}=1.356)$. In
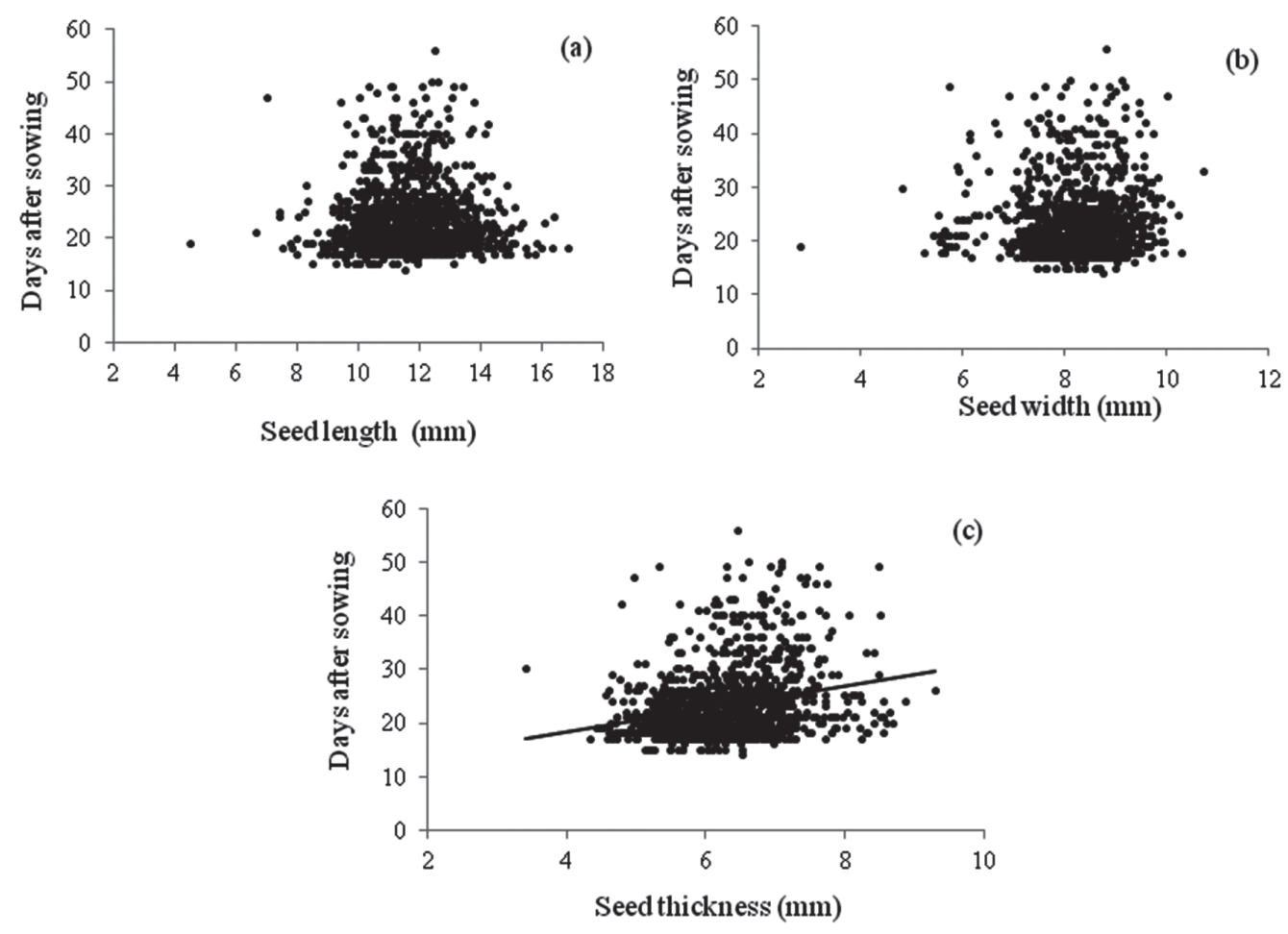

Figure 3. Relationships between Copaifera langsdorffii seed morphometrics and time to seedling emergence. 

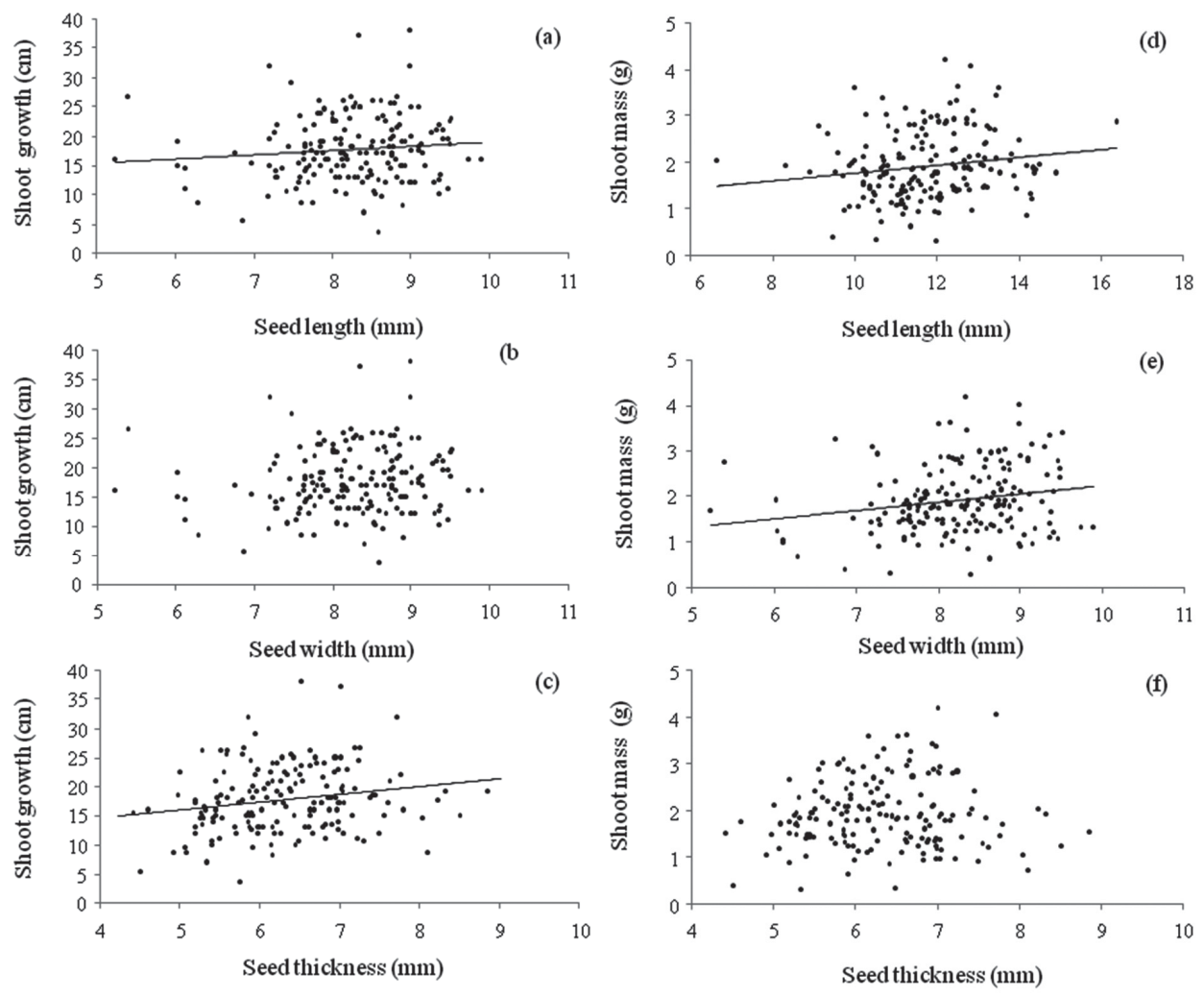

Figure 4. Seed morphometrics in relation to shoot growth and dry mass of Copaifera langsdorffii seedlings.
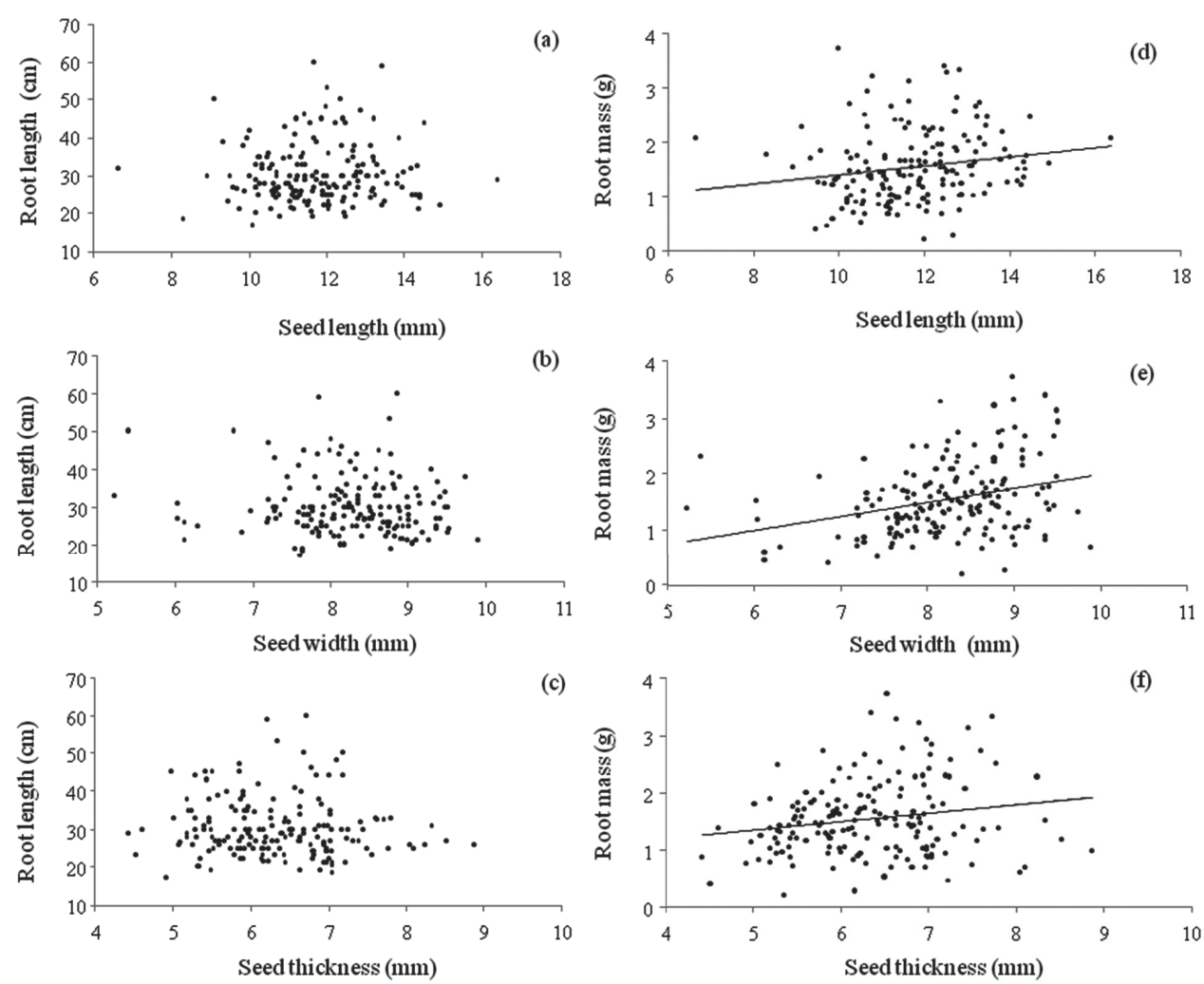

Figure 5. Seed morphometrics in relation to root length and root dry mass of Copaifera langsdorffii seedlings. 

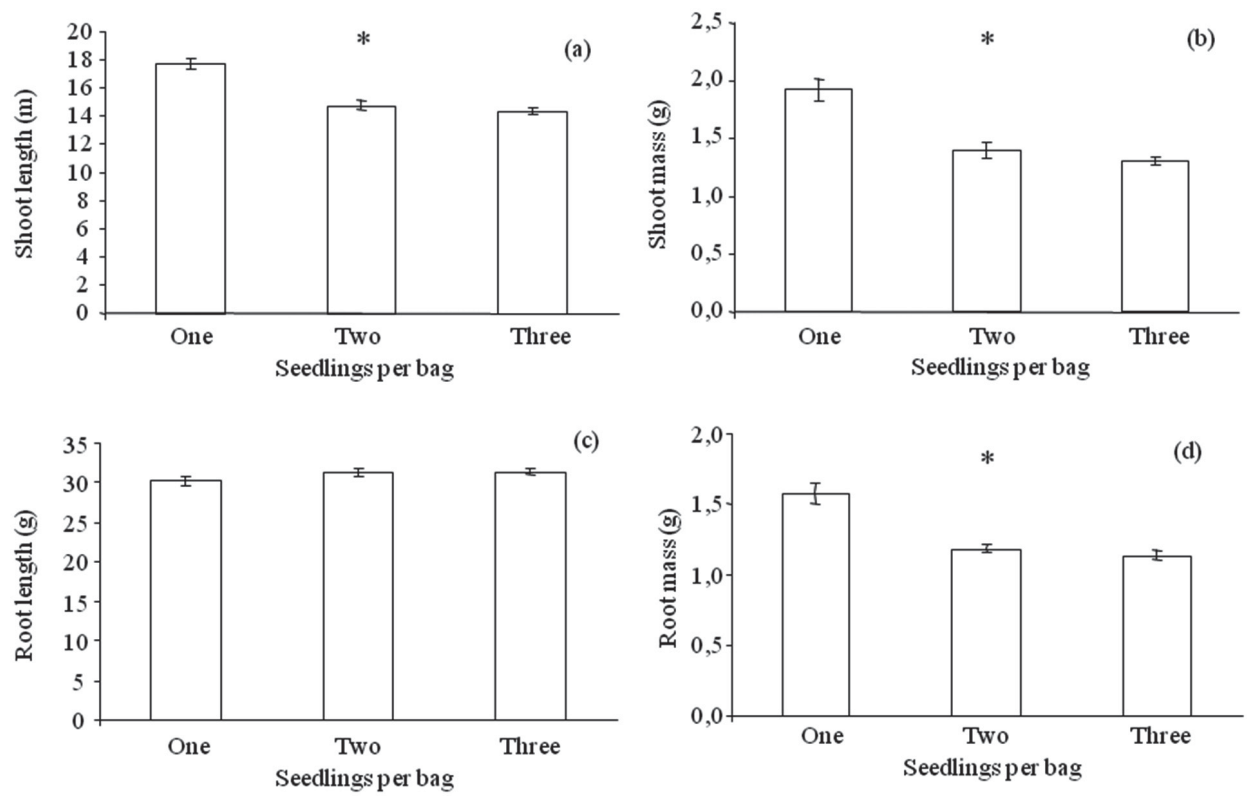

Figure 6. The effect of the number of plants per plastic bag on Copaifera langsdorffii seedling shoot and root development. (Values are mean $\pm \mathrm{SD}$; ${ }^{*}$ statistical difference between treatments).

addition, as shown in Tab. 1, contrast analysis revealed that seedlings cultivated individually $\left(\mathrm{t}_{1}\right)$ presented greater shoot length, shoot dry mass and root dry mass when compared with seedlings cultivated in groups $\left(\mathrm{t}_{2}\right.$ and $\mathrm{t}_{3}$ treatments).

\section{Discussion}

The negative relationship between the number of fruits per plant and attacks by Rhinochenus brevicollis on Copaifera langsdorffii seeds observed in this study indicates that there was less seed predation on plants that presented greater numbers of fruits. Therefore, our data do not support the resource concentration hypothesis. It is important to emphasize that the proportion of $C$. langsdorffii seeds that escaped predation by $R$. brevicollis was greater on plants that produced greater numbers of fruits. Ramirez \& Arroyo (1987) also observed less pre-dispersal seed predation by insects in patches with a high density of C. pubiflora seeds. C. langsdorffii is a supra-annual, mass-fruiting species, and this phenological pattern may be an efficient strategy to increase the number of seeds that escape predation due to predator satiation (Shibata et al. 1998; Kon et al. 2005; Tsvuura et al. 2010). Therefore, it is likely that the negative relationship between percentage seed predation and total number of seeds per plant observed in this study can be associated with $R$. brevicollis satiation (Silvertown 1980; Ramírez \& Traveset 2010).

Historically, plants within a given population have been thought to develop seeds of similar size because there is always a single seed size that optimizes the local fitness (Rees \& Westoby 1997). However, seed size within species is a plas- tic component of plant life history strategies (Harper et al. 1970). The variation in seed size within species is probably associated with differential seed performance among habitats (Bu et al. 2009). Theoretically, small seeds are expected to have a competitive advantage over larger seeds in stressed habitats by having faster emergence, since small seeds have proportionally greater surface area for water absorption (Sadeghi et al. 2011). In contrast, larger seeds germinate more slowly and present greater percentage emergence in more predictable habitats (Ferreira \& Borghetti 2004). Some studies developed in controlled environments also have reported the absence of a relationship between seed size and germinability (Gharoobi 2011; Mwase \& Mvula 2011), while other studies emphasize the importance of the interaction between seed size and moisture stress for seed germinability (Mwase \& Mvula 2011; Farahani et al. 2011). In the present study, the percentage seedling emergence did not differ among size classes, and only seed thickness affected time to emergence. In this scenario, we suggest that the observed absence of a relationship between seed size and germinability may be an artifact of experimental environmental homogeneity, especially of water irrigation and soil quality (Farahani et al. 2011).

Most studies agree that large seeds tend to produce larger seedlings (Leishman et al. 2000). However, this pattern can be maintained until plant maturity or this initial size advantage of seedlings from large seeds may disappear with time (Cordazzo 2002; Socolowski et al. 2011). In addition, the results of interaction between seed size and seedling development can also be affected by light intensity (Socolowski et al.2011), water stress (Kaydan \& Yagmur 2008), soil quality (Alcántara et al. 2004) and biotic interactions (Silvertown 
Table 1. Contrast analysis showing the effects of the treatments on the response variables.

\begin{tabular}{lcccc}
\hline Response variable & Comparison & Mean square & $\mathrm{F}$ & $\mathrm{p}$ \\
\hline \multirow{2}{*}{ Root dry mass } & $\mathrm{t}_{2}$ vs. $\mathrm{t}_{3}$ & 0.362 & 1.149 & 0.284 \\
& $\mathrm{t}_{2}$ and $\mathrm{t}_{3}$ vs. $\mathrm{t}_{1}$ & 19.045 & 60.341 & $<0.01$ \\
Shoot dry mass & $\mathrm{t}_{2}$ vs. $\mathrm{t}_{3}$ & 1.291 & 3.526 & 0.061 \\
& $\mathrm{t}_{2}$ and $\mathrm{t}_{3}$ vs. $\mathrm{t}_{1}$ & 42.494 & 117.252 & $<0.01$ \\
Shoot length & $\mathrm{t}_{2}$ vs. $\mathrm{t}_{3}$ & 33.205 & 1.271 & 0.260 \\
& $\mathrm{t}_{2}$ and $\mathrm{t}_{3}$ vs. $\mathrm{t}_{1}$ & 1329.070 & 50.855 & $<0.01$ \\
\hline
\end{tabular}

$t_{1}$ - one seed per plastic bag; $t_{2}$ - two seeds per plastic bag; $t_{3}$ - three seeds per plastic bag.

\& Bullock 2003). In general, the results of the present study reveal that Copaifera langsdorffii seedlings originating from larger seeds presented greater development of shoots and roots (only root length was unaffected by seed size). The absence of a relationship between seed size and root length is probably associated with the limited capacity of the plastic bags, which may have inhibited the development of the axial root. Therefore, the general relationships between seed morphometry and seedling development observed in our study confirms the initial prediction that larger seeds tend to produce more vigorous seedlings in C. langsdorffii.

The results of this study also show that density of seedlings per plastic bag negatively affected the initial growth of Copaifera langsdorffii in greenhouse conditions. The above- and below-ground seedling competition is an important mechanism that determines plant survival and community organization (Lentz 1999; Dickie et al. 2005; Kueffer et al. 2007). However, the result of the competition among seedlings is heavily habitat-dependent. In habitats with low productivity, below-ground competition for nutrients is likely to be more important than is above-ground competition (Kuefer et al. 2007). The soil used as substrate for seedling growth (dystrophic cerrado soil) is poor in nutrients (Fagundes et al. 2011). In addition, given their architecture, C. langsdorffii plants may not shade neighbors to a great extent at the seedling stage. Therefore, it is possible that the below-ground competition for limited nutrients in the soil was the mechanism responsible for the impaired $C$. langsdorffii seedling development observed.

Finally, our findings suggest that the ability of Copaifera langsdorffii to colonize and establish itself in nutrientlimited soils is controlled by historical and ecological process. For example, from an evolutionary perspective, the supra-annual plant phenology promotes greater seed survival within the population because irregular seed production from year to year would reduce the population of seed predators (Silvertown 1980). In addition, the elevated number of seeds produced in reproductive years and the variation in seed size allows the species to colonize different habitats, because the relationship between seed size and seedling vigor is habitat-dependent. In a local and ecological context, seed predation and seedling competition may regulate plant population density.

\section{Acknowledgments}

We thank J.P. Mata and R. Reis-Junior for their insightful comments on earlier drafts of the manuscript, as well as the two anonymous referees who made valuable contributions to this manuscript. This study received financial support from the Fundação de Amparo à Pesquisa do Estado de Minas Gerais (FAPEMIG, Foundation for the Support of Research in the State of Minas Gerais; grant no APQ-01231-09 to MF).

\section{References}

Baraloto, C. \& Forget, P.M. 2007. Seed size, seedling morphology and response to deep shade and damage in neotropical rain forest trees. American Journal of Botany 94: 901-911.

Bezerra, A.M.E.; Medeiros, S.F.; Moreira, M.G.; Moreira, F.J.C. \& Alves T.T.L. 2002. Germinação e desenvolvimento de plântulas de copaíba em função do tamanho e da imersão da semente em ácido sulfúrico. Revista de Ciências Agronômicas 33: 5-12.

Bu, H.Y.; Du, G.Z.; Chen, X.L.; Wang, Y.; Xu, X.L. \& Liu K. 2009. The evolutionary significance of seed germinability in an Alpine Meadow on the Eastern Qinghai-Tibet Plateau. Arctic, Antarctic, and Alpine Research 41: 97-102.

Casper, B.B. \& Jackson, B.R. 1997. Plant competition underground. Annual Review of Ecology and Systematic 28: 545-570.

Cordazzo, C.V. 2002. Effect of seed mass on germination and growth in three dominant species in southern Brazilian coastal dunes. Brazilian Journal of Biology 62: 427-435.

Costa, F.V.; Fagundes, M.F.; Neves, F.S. 2010. Arquitetura da planta e diversidade de galhas associadas à Copaifera langsdorffii (Fabaceae). Ecología Austral 20: 9-17

Costa, F.V.; Siqueira, F.N.; Oliveira, J.S. \& Fagundes, M. 2011. Relationship between plant development, tannin concentration and insects associated with Copaifera langsdorffii (Fabaceae). Arthropod-Plant Interactions 5: 9-18.

Czarnecka, B. \& Władyka, M. 2007. Ecological meaning of seed size and shape for seed persistence and germinability in some mountain plants from the collection of the Botanical Garden in Lublin. Bulletin of Botanical Gardens 16: 3-107.

Dickie, I.A.; Schnitzer, S.A.; Reich, P.B. \& Hobbie, S.E. 2005. Spatially disjunctive effects of co-occurring competition and facilitation. Ecology Letters 8: 1191-1200.

Fagundes, M.; Camargos, M.G. \& Costa, F.V. 2011. A qualidade do solo afeta a germinação das sementes e o desenvolvimento das plântulas de Dimorphandra mollis (Fabaceae). Acta Botanica Brasilica 25: 908-915.

Fagundes, M.; Costa, F.V.; Maia, M.L.B.; Queiroz, A.C.M.; Fernandes, G.W. 2013. Seed predation of Copaifera langsdorffii Desf. (Fabaceae: Caesalpinioideae) by Rhinochenus brevicollis Chevrolat (Coleoptera: Curculionidae) in a Brazilian Cerrado Fragment. Ecología Austral (in press). 
Farahani, H.A.; Moaveni, P. \& Maroufi, K. 2011. Effect of seed size on seedling production in wheat (Triticum aestivum L.). Advances in Environmental Biology 5: 1711-1715.

Ferreira, A.G. \& Borghetti, F. 2004. Germinação: do básico ao aplicado. Artmed, Porto Alegre.

Freitas, C.V. \& Oliveira, P. 2002. Biologia reprodutiva de Copaifera langsdorffii Desf. (Leguminosae, Caesalpinoidea). Revista Brasileira de Botânica 25: 311-321.

Francisco, M.R.; Lunardi, V.O.; Guimarães, P.R. \& Galetti, M. 2008. Factors affecting seed predation of Eriotheca gracilipes (Bombacaceae) by parakeets in a cerrado fragment. Acta Oecologica 33: 240-245.

Gharoobi, B. 2011. Effects of seed size on seedlings characteristics of five barley cultivars. Iranian Journal of Plant Physiology 1: 265-270.

Geritz, S.A. 1995. Evolutionarily stable seed polymorphism and small-scale spatial variation in seedling density. America Naturalist 146: 685-707.

Green, P.T. \& Juniper, P.A. 2004. Seed-seedling allometry in tropical rain forest trees: seed mass-related patterns of resource allocation and the 'reserve effect'. Journal of Ecology 92: 397-408.

Harper, J.L.; Lovell, P.H. \& Moore, K.G. 1970. The shapes and size of seeds. Annual Review of Ecology and. Systematic 1: 327-356.

Harper, J.L. 1977. Population biology of plants. New York, Academic Press.

Hulme, P.E. \& Benkman, C.W. 2002. Granivory. Pp.132-154. In: Herrera, C.M. \& Pellmyr, O. (Eds.). Plant Animal interactions: An evolutionary approach. Oxford, Blackwell Science.

Janzen, D.H. 1971. Seed Predation by Animals. Annual Review of Ecology and. Systematic 2: 465-492.

Janzen, D.H. 1975. Behavior of Hymenaea courbaril when its predispersal seed predator is absent. Science 189: 145-147.

Kidson, R. \& Westoby, M. 2000. Seed mass and seedling dimensions in relation to seedling establishment. Oecologia 125: 11-17.

Kaydan, D. \& Yagmur, M. 2008. Germination, seedling growth and relative water content of shoot in different seed sizes of triticale under osmotic stress of water and $\mathrm{NaCl}$. African Journal of Biotechnology 7: 2862-2868.

Kon, H.; Noda, T.; Terazawa, K.; Koyama, H. \& Yasaka, M. 2005. Evolutionary advantages of mast seeding in Fagus crenata. Journal of Ecology 93: $1148-1155$

Kueffer, C.; Schumher, E.; Fleischmann, K., Edwards, P.J. \& Dietz H. 2007. Strong below-ground competition shapes tree regeneration in invasive Cinnamomum verum Forests. Journal of Ecology 95: 273-282.

Kull, T.; Kull, T. \& Sammul, M. 2011. Reduced light availability and increased competition diminish the reproductive success of wet forest sedge Carex loliacea L. Plant Species Biology 26: 84-92.

Leishman, M.R.; Wright, I.J.; Moles, A.T. \& Westoby, M. 2000. The evolutionary ecology of seed size. Pp.31-57. In: Fenner. M. (Ed.). Seeds: the ecology of regeneration in plant communities. Wallingford, CAB International.

Lemaire, G. 2001. Ecophysiological of Grasslands: Dynamics aspects of forage plant population in grazed swards. Journal of Experimental Botany 50: 10-21.

Lentz, K.A. 1999. Effects of intraspecific competition and nutrient supply on the endangered northeastern bulrush, Scirpus ancistrochaetus Schuyler (Cyperaceae). The American Midland Naturalist 142: 47-54.

Lewis, O.T. \& Gripenberg, S. 2008. Insect seed predators and environmental change. Journal of Applied Ecology 45: 1593-1599.

Louda, S.M.; Potvini, M.A. \&. Collinge, S.K. 1990. Predispersal Seed Predation, Postdispersal Seed Predation and Competition in the
Recruitment of Seedlings of a Native Thistle in Sandhills Prairie. The American Midland Naturalist 124: 105-113

Marques, M.C.M. \& Oliveira, P.E.A.M. 2005. Características reprodutivas das espécies vegetais da planície litorânea. História Natural e Conservação da Ilha do Mel. Curitiba, Editora da Universidade Federal do Paraná.

Moles, A.T.; Ackerly, D.D.; Webb, C.O.; Tweddle, J.C.; Dickie, J.B. \& Westoby, M. 2005. A brief history of seed size. Science 307: 576-580.

Mwase, W.S. \& Mvula, T. 2011. Effect of seed size and pre-treatment methods of Bauhinia thonningii Schum. on germination and seedling growth. African Journal of Biotechnology 10: 5143-5148.

Pedroni, F.; Sanchez, M. \& Santos, F.A.M. 2002. Fenologia da copaíba (Copaifera langsdorffii Desf. - Leguminosae, Caesalpinoidea). Revista Brasileira de Botânica 25: 183-194.

Platt, K.H.; Allen, R.B.; Coomes, D.A. \& Wiser, S.K. 2004. Mountain beech seedling responses to removal of below-ground competition and fertiliser addition. New Zealand Journal of Ecology 28: 289-294.

Ramírez, N. \& Arroyo, M.K. 1987. Variacion espacial y temporal en la depredacion de semillas de Copaifera publiflora Benth. (Leguminosae: Caesalpinioideae) en Venezuela. Biotropica 19: 32-39.

Ramírez, N. \& Traveset, A. 2010. Predispersal seed-predation by insects in the Venezuelan central plain: overall patterns and traits that determine its incidence. Perspective in Plant Ecology, Evolution and Systematics 12: 193-209.

Rees, M. \& Westoby, M. 1997. Game-theoretical evolution of seed mass in multi-species ecological models. Oikos 78: 116-126.

Ribeiro, M.C.C.; Marques, B.M. \& Amarro Filho, J. 2001. Efeito da salinidade na germinação de sementes de quatro cultivares de girassol (Helianthus annuus L.). Revista Brasileira de Sementes 23: 281-284

Rizzini, C.T. 1997. Tratado de fitogeografia do Brasil: aspectos ecológicos, sociológicos e florísticos. Rio de Janeiro, Âmbito Cultural.

Root, R.B. 1973. Organization of a plant-arthropod association in simple and diverse habitats: the fauna of collards (Brassica oleracea). Ecological Monographs 43: 95-124.

Sadeghi, H.; Khazaei, F.; Sheidaei, S. \& Yari, L. 2011. Effect of seed size on seed germination behavior of safflower (Carthamus tinctorius L.). Journal of Agricultural and Biological Science 6: 5-8.

Shibata, M.; Tanaka, H. \& Nakashizuka, T. 1998. Causes and consequences of mast seed production of four co-occurring Carpinus species in Japan. Ecology 79: 54-64.

Silvertown, J.W. 1980. The evolutionary ecology of mast seeding in trees. Biological Journal of the Linnean Society 14: 235-250.

Silvertown, J. \& Bullock, J.M. 2003. Do seedlings in gaps interact? A field test of assumptions in ESS seed size models. Oikos 101: 499-504.

Socolowski, F.; Vieira, D.C.M. \& Takak, M. 2011. Massa das sementes de Tecoma stans L. Juss. ex Kunth (Bignoniaceae): efeitos na emergência e desenvolvimento de suas plântulas no sol e na sombra. Biota Neotropica 11: 171-178.

Susko, D.J. \& Lovett-Doust, L. 1999. Effects of resource availability, and fruit and ovule position on components of fecundity in Alliaria petiolata (Brassicaceae). New Phytologist 144: 295-306.

Tsvuura, Z.; Griffiths, M.E.; Gunton, R.M.; Franks, P.J. \& Lawes, M.J. 2010. Ecological filtering by a dominant herb selects for shade tolerance in the tree seedling community of coastal dune forest. Oecologia 164: 861-870.

Turner, I.M.; Tan, H.T.W. \& Chua, K.S. 1996. Relationships between herb layer and canopy composition in tropical rain forest successional mosaic in Singapore. Journal of Tropical Ecology 12: 843-851. 